\title{
Organic Weed Control
}

\author{
Charles L. Webber III ${ }^{1}$, James W. Shrefler ${ }^{2}$ and Lynn P. Brandenberger ${ }^{3}$ \\ ${ }^{1} U S D A$, ARS, WWARL, Lane, Oklahoma, \\ ${ }^{2}$ Oklahoma State University, Lane, Oklahoma \\ ${ }^{3}$ Oklahoma State University, Stillwater, Oklahoma
}

USA

\section{Introduction}

Organic vegetable producers rank weeds as one of their most troublesome, time consuming, and costly production problems (OFRF, 1999). Because there are only a few organically approved herbicides, optimizing their application may increase their potential usefulness for organic production systems. Inter-row cultivation for the purpose of weed control is not always the ideal choice for organic vegetable production or due to soil and weather conditions may not always be an available option. Additional cultivations can decrease soil organic matter (Dick, 1983; Gallaher \& Ferrer, 1987; Johnson, 1986) and soil water holding capacity (Johnson, 1986), increase soil erosion (Logan et al., 1991; McDowell \& McGregor, 1984) and nutrient loss (McDowell and McGregor, 1984), and stimulate new weed growth (Pekrun et al., 2003). In conventional, non-organic production systems, herbicides are increasingly used to avoid the detrimental impact of soil erosion from weed control from cultivation. Preventing soil, nutrient, and organic matter losses due to tillage are a fundamental tenant of certified organic production (USDA National Organic Standards Board, 2010).

The primary source for the majority of organic herbicides are natural, produced by or from plants. Allelopathy is the biochemical interference, inhibitory or stimulatory, between one plant species and another (Rice, 1984). Certain weeds and crops can release chemicals by exudation, leaching, volatilization, and from plant tissue (leaves, stems, roots, flowers) decomposition into the environment. When these biochemcals (allelochemicals) come contact with other plants they can influence (inhibit or simulate) another species growth. Vegetables are not immune to allelopathic effects of other crops. Early development of vegetables may be the most vulnerable part of the life cycle to be exposed to allelopathic chemicals (Russo et al., 1997). The allelopathic impact of one species upon another is more obvious when the allelochemcials prevent germination and establishment of an affected species, but the impact exerted can affect established neighboring plants by limiting their optimum growth or causing death. Allelochemicals can persist in the soil, and therefore, impact the subsequent crop growth. Allelochemicals can also work in concert with competition for light, water, and nutrients between weeds and crop plants. Microbial weed control is another method for managing weeds (see chapter "Microbial weed control and microbial herbicides" by Tami L. Stubbs and Ann C. Kennedy) with potential application within an organic cropping system. 
Organic certification in the United States was developed in recognition of the necessity for the use of consistent standards across the U.S. to benefit producers, processors, wholesalers, retailers, and consumers. Prior to establishment of USA's, National Organic Program federal guidelines for organic certification in 2002, a multitude of agencies and associations throughout the U.S. maintained a diverse list of acceptable inputs, production methods, and policies to determine organic certification, which were consistently reviewed with materials being added or removed from use. Differences in certification standards invited marketing inconsistencies, misunderstandings, and misrepresentations concerning organic products. Certified organic crop production is more than a list of acceptable and prohibited inputs or practices that can and can not be used; rather, it is a holistic approach to sustainable and healthy food production that enhances the well-being of the consumer and protects natural resources. One important aspect of certified organic crop production is the prevention of non-organic substances from intentionally, or inadvertently, being brought into the production area. This would include the intentional application of irrigation water, or natural water flow containing disallowed materials, including herbicides, from a pond or lake onto a certified organic production area.

The approval process for herbicides for certified organic production initially follows a similar registration process as conventional herbicides, through US government (United States Environmental Protection Agency) and state approval. A potential organic herbicide must also be cleared by the National Organic Program (NOP) and the individual farmer's certifying agency. The Organic Materials Review Institute (OMRI) is a nonprofit organization founded in 1997 to provide a independent review of potential organic products. OMRI is not a regulating agency, but the agencies or companies which certify organic producers tend to place a great importance on whether a material has been placed on the OMRI approval list. A particular product or material may be appropriate and safe for use on certified organic land even if the product is not on the OMRI list, but the individual farmer's certifying agency must agree that the product can be used in connection with certified organic land and produce. The producer should always check with their certifying agency prior to using any product or material. As with conventional herbicide labels, regulations, approvals, and labels for organic herbicides can and often do change often. The term "organic" has its detractors. The term "natural" is preferred by some. As the legislation stands only the term "organic" is recognized.

Human safety should always remain a primary concern when using any herbicide, even organically approved herbicides. For example, eye exposure to vinegar with acetic acid concentrations greater than $10 \%$ can cause blindness. In this chapter the most common organic herbicides and their methods of application are described. The reader should be aware that herbicide labels and regulations can and do change. The herbicides described are not meant to be all inclusive, but to provide information on the more common organic herbicides. Certain herbicides or formulations may have been dropped or added, so all herbicide labels should be read and followed closely. Sometimes organic herbicides fail, the same can be true for synthetic herbicides, in which case it is necessary to use hand tools or cultivation to control weeds. Although hoeing is labor intensive and tedious early preemptive use of tools for weed control can provide reduced time for weeding later in the growing season. 


\section{Holistic weed control}

Organic producers typically understand better than others the importance of a holistic approach to crop production and weed control. The initial site selection for a certified organic production area can have tremendous long term benefits, or adverse consequences, for crop yields and weed control. Although any site that is selected may have some indigenous weed species, either present or stored in the soil profile, it is critical to select land that minimize these weed sources, and then pursue a diligent program to control existing weeds and prevent the introduction of new weeds. Many of the certification requirements favor site selections and processes that help reduce weed growth and the introduction of new weeds (e.g., avoiding drainage into the certified area, good soil health and conservation, cover crops and mulches, and cleaning equipment entering from not certified areas).

\subsection{Weed monitoring}

Weed monitoring is an essential aspect for the successful and economic control of weeds. It is important to determine the weed species and their locations in the production area. Weed monitoring should not be limited to the current growing season, but throughout the year, and from year to year, so that trends in weed populations can become known. Ideally, weed surveys should be conducted twice during each growing season, once following planting but prior to the first weeding/post-emergence application and then just prior to harvest. The survey results will provide valuable information concerning the weeds missed from previous crops and current preemergence and post-emergence weed control efforts and potential weeds from crop rotations. Weed monitoring throughout the year will help the producer to realize the importance of controlling weeds year long. A single uncontrolled weed can produce 10s of thousands of weed seed. Take for example one of many weed species that can inflect total yield loses, if left uncontrolled: redroot pigweed (Amaranthus retroflexus L.). Researchers have reported that a typical redroot pigweed can produce from 9,254 (Pawlowski et al., 1970) to 117,400 (Stevens, 1932) seeds per plant. A vigorous redroot pigweed plant may produce 100,000 seeds (Mitich, 1997), a large plant can produce as many as 230,000 seeds (Stevens, 1957), and closely spaced plants 34,600 seeds/plant (Hauptli \& Jain, 1978; Weaver \& McWilliams, 1980). In addition to the large number of seeds produced from a single plant, the seeds can overwinter in the flowers (Mohler \& Callaway, 1995), and on or below the soil surface (Georgia, 1942), and are known to survive in the soil for 30 (Mitich, 1997) to 40 years (Darlington \& Steinbauer, 1961). Therefore, a few escape plants even at the end of growing season can have long-term detrimental impact on future weed infestations, weed control costs, and yield reductions. Redroot pigweed is only one of many weed species that have these tremendous competitive tendencies. Producer should be especially concerned with aggressive and hard to control perennial weeds such as nutsedges (Convolvulus arvensis L. and bindweeds [Calystegia sepium (L.) R. Br.], for once they are established they are very difficult to eliminate. Weed monitoring will also assist the producers in making informed decisions concerning crop rotations, rotating herbicides, and cultural practices.

\subsection{Weeds: opportunistic plant species}

Research and grower experience have shown the importance of crop rotations, cover crops, and mulches for crop and soil health, and reduced weed competition. Weeds are 
opportunistic plant species that will occupy voids between crop sequences, crop rows, and crop plants within rows. The judicious selection of beneficial plant species that will fill these voids between growing seasons, and cover the soil surface as mulches, can promote crop productivity by increasing nutrients, organic matter, preserving soil moisture, and reducing weed competition. Great care must be taken when using plant mulches from locations other than your own certified land to prevent the introduction of additional weeds to your production area. In the same manner, the use of animal manures from outside sources may introduce new weeds. If a new weed species does appear, take immediate action to eliminate the plants, minimize seed dispersal, and determine the source of infestation.

\subsection{Cultural practices}

\subsubsection{Crop rotations, and stale seedbeds}

Crop rotations, including winter cover crops, can influence the quantity and species of weed present in spring-planted crops. The previous cropping systems may influence weed pressure during the current growing season depending on the type of crop produced, the herbicides used, and the weeds controlled or not controlled. The presence of a winter cover crop prior to establishment of a spring crop can reduce the weed pressure in the following crop by not allowing weeds to become established during non-production times. Clark and Panciera (2002) reported that rolling down a winter rye crop suppressed weeds in the following spring no-till planted corn crop, eliminating the need for herbicides. Rolling winter rye or a winter rye/hairy vetch mixture suppressed weeds in spring no-till planted bell peppers by $96 \%$ for 8 to 10 weeks, while rolling hairy vetch alone reduced weeds by $80 \%$ for 2 to 8 weeks (Leavitt et al., 2011). When rolling is used a machine comprised of a drum roller, to which blunt metal strips were welded either horizontally or in a chevron pattern, is drawn over the standing cover crop. The metal strips crush and crimp the stems without chopping. The cover is killed and the residue left after use of a roller-crimper is laid down flat in a uniform direction and layered so that the space through which weeds can emerge is reduced (Teasdale \& Mohler, 2000).

Crop rotation can also help prevent domination of any one weed species. The herbicides used in a previous crop may eliminate potentially hard to control weeds or inadvertently select for more troublesome weeds in future crops. Weed management, monitoring and control, should focus not only on the current crop, but also on the weed management systems prior to the current crop. The previous herbicides may not only impact the weeds in the current crop, but may also have detrimental herbicide carry over.

Stale seedbeds and reduced tillage practices can be used in conjunction with many of the other organic weed control practices. In a stale seedbed, the planting area is prepared earlier than normal to allow for the germination, growth and control of weeds, or the killing of an established cover crop to serve as a mulch. The weeds or the cover crop might be killed with a mower, a chopper, organic herbicides, or by some other means. The crop is then directseeded, or transplanted into the seedbed using a minimal amount of soil disturbance in order to not promote weed seed germination and growth.

\subsubsection{Solarization and tillage}

Solarization and fallow tillage are two other approaches that use the weeds' aggressive growth tendencies as a method to help control future weed competition. Solarization is the 
use of solar radiation to kill weeds, normally using clear polyethylene mulch on moist soil surfaces. Solar radiation passes through the clear plastic, heating the soil. The moist hot environment initiates weed seed germination and stimulates weed growth, but then the hot humid confined environment becomes detrimental to continued weed growth and survival (Johnson et al., 2007). Solarization can also benefit the future crop by adversely impacting other plant pests such as nematodes, fungi, and insects (Johnson et al., 2007). Fallow tillage is the repeated use of soil tillage on fallow land to reduce future weed populations (Johnson et al., 2007). The weeds are repeatedly allowed to germinate and grow, but tilled prior to seed production. Fallow tillage can be used independently or in conjunction with solarization or other organic weed control methods (Johnson et al., 2007). During the cropping season, paper, fiber, and colored plastic mulches serve as weed barriers while promoting crop growth by warming the soil and conserving soil moisture. Soil cultivation during the growing season is also an effective method for controlling weeds between crop rows until canopy closure between rows. Hoeing and hand-weeding is also an option, depending on the production area, labor impacts on return on investment, and the removal of newly induced weed species.

\subsubsection{Mulches}

The term mulch has an expansive degree of understanding depending on by whom, and how, it is being used. Mulch can be defined as use of a material that covers soil for a variety of uses. The term was at one time used for the application of organically based plant residue. The term mulch has grown to incorporate the use of paper and plastics applied from a roll or polymers applied to the soil (Russo, 1995). Plastic mulch can be applied from a tractor mounted implement that lays the material on to the soil and covers the edge so that the plastic is secured to a bed. A drip irrigation system can be applied at the same time as the plastic mulch with the same implement. Plastic of several colors have been tested with crops and it was determined that they affected plant development and yield (Decoteau et al., 1990; Kaul \& Kasperbauer, 1992).

Plastic and natural (dead or living) mulches are used to control weeds (Law et al., 2006). Mulches are typically applied to a prepared bed prior to transplanting. However, if stale seed beds are used the mulch can be applied in the autumn before a next spring's planting. Plastic mulches used in conjunction with an irrigation system under the plastic have the advantage that the soil temperature is generally increased and the soil moisture conserved which benefits crop growth while serving as a barrier to weed establishment (Law et al., 2006). Most weeds will germinate and emerge under the plastic mulches but will die due to the lack of sunlight and/or excessive temperatures. However, nutsedges (e.g., Cyperus esculentus L. and Cyperus rotundus L.) may actually pierce the thinner plastic mulches and reduce pepper yields through competition. Certain plastic mulches can be used in both conventional and organic production systems. Dead natural mulches can reduce weed populations and increase crop yields. In a 2-yr study, a cowpea mulch reduced weeds at harvest by 80 and $90 \%$ and increased bell pepper yields by 202 and $165 \%$ compared to plots with the plastic mulch (McGiffen \& Hutchinson, 2000). Living mulches can also provide weed suppression for spring-transplanted crops (Paine \& Harrison, 1993), but can also reduce pepper yields (Biazzo \& Masiunas, 1998). 


\subsubsection{Flaming}

Flaming uses propane gas (LP, LPG, LP-gas) to control weeds with a directed flame (Johnson \& Mullinix, 2008). Flaming equipment can either be LP hand-held devices or full size field flamers with multiple flamers across the width of the boom flame (Johnson \& Mullinix, 2008; OFRF, 2006). Flaming research has produced mixed results depending on the equipment used, the weed species and size, and the exposure time to the flaming treatment. Research investigating organic weed control methods on stale seedbeds determined that a hand-held LP flamer produced better and more convenient weed control than a number of organic herbicides containing either clove oil and/or acetic acid (OFRF, 2006). The researchers did state that flaming was their least favorite method "due to it being a nonrenewable resource." Other researchers have reported unsatisfactory results with full size flaming equipment due to safety and operational issues, and ineffective weed control, especially with consistent long term control of grasses.

\subsection{Organic herbicides}

\subsubsection{Preemergence organic herbicides}

\subsubsection{Corn gluten meal}

Corn gluten meal (CGM) is an organic herbicide (Bingaman and Christians, 1995; Christians, 1991). CGM is the by-product of the wet-milling process of corn (Bingaman and Christians, 1995; Quarles, 1999). The protein fraction of CGM is approximately $60 \%$ protein and $10 \%$ nitrogen (Quarles, 1999). CGM (Alliance Milling Company, Denton TX), normally a yellow powder (McDade, 1999), has been used as a component in dog, fish, and livestock feed (Christians, 1991, 1995; Quarles, 1999). CGM can be purchased in the form of a powder, a pellet, and a granulated material (McDade, 1999; Webber and Shrefler, 2007a).

Christians (1993) investigated the weed control efficacy of broadcast soil applied, nonincorporated, applications of corn starch, corn germ, corn seed fiber, corn meal, and CGM. CGM produced the greatest inhibitory effect and reduced root formation in several weed species, including creeping bentgrass (Agrostis palustris) and crabgrass (Digitaria ssp.). Bingaman and Christians (1995) in greenhouse research determined that CGM applied at $324 \mathrm{~g} \cdot \mathrm{m}^{-2}$ reduced plant survival, shoot length, and root development for the twenty-two weed species tested, whether the CGM was applied to the soil surface as a preemergence herbicide or mixed into the top $2.54 \mathrm{~cm}$ as a preplant-incorporated herbicide. Although plant development was reduced for all weeds tested, the extent of susceptibility differed across species. Plant survival and root development were reduced by at least $70 \%$ and shoot length by at least $50 \%$ for the weeds: black nightshade (Solanum nigrum), common lambsquarters (Chenopendium album), creeping bentgrass, curly dock (Rumex crispus), purslane (Portulaca oleracea), and redroot pigweed (Amaranthus retroflexus). When CGM was applied preplant-incorporated, survival and shoot length of the following weeds were reduced at least $50 \%$ and root development reduced by at least $80 \%$ : catchweed bedstraw (Galium aparine), dandelion (Taraxacum officinale), giant foxtail (Setaria faberi), and smooth crabgrass (Digitaria ischaemum). Barnyardgrass (Echinochloa crus-galli) and velvetleaf (Abutilon theophrasti) were more tolerant to CGM and plant survival reductions were less than 31\%. Field studies with three planting dates (3 July 1998, 20 Aug. 1998, and 8 June 1999) demonstrated that CGM incorporated into the top 5-8 cm of soil at 100, 200, 300, and 400 
g. $\mathrm{m}^{-2}$ reduced weed cover by $50 \%, 74 \%, 84 \%$, and $82 \%$, respectively, compared to an untreated check at 3 weeks after treatment (McDade \& Christians, 2000).

Crop safety with CGM is a major concern because it is a non-selective organic herbicide. CGM applications for organic weed control did not adversely affect established turf (Christians, 1993). Nonnecke and Christians (1993) did report a decrease in strawberry (Fragaria xananassa) fruit number and weight from four applications of CGM, but it was unclear whether the yield reductions were due to the CGM phytotoxicity or excess nitrogen applications associated with CGM (10\% nitrogen). Strawberry leaf area was not reduced as a result of CGM applications (Nonnecke \& Christians, 1993). In onions, CGM applications of $400 \mathrm{~g} \cdot \mathrm{m}^{-2}$ to spring-transplanted onions produced fair $(72.1 \%)$ overall weed control and good $(82.7 \%)$ broadleaf weed control through the first $46 \mathrm{~d}$ after planting (DAP) (Webber et al., 2007a), without reductions in yields from crop injury (Webber et al., 2007b).

The impact of CGM applications on the plant safety of direct-seeded crops has been investigated by McDade and Christians (2000) and Webber and Shrefler (2007b). McDade and Christians (2000) determined that CGM rates of 100, 200, 300, and 400-g.m-2 CGM rates reduced average seedling survival for eight vegetables by $48 \%, 65 \%, 73 \%$, and $83 \%$, respectively. 'Daybreak' sweet corn (Zea mays) was the most tolerant to CGM, requiring at least $300 \mathrm{~g} \cdot \mathrm{m}^{-2}$ of CGM to produce a $26 \%$ reduction in stand. CGM applications of $100 \mathrm{~g} \cdot \mathrm{m}^{-2}$ reduced seedling survival by 35\% for 'Ruby Queen' beet (Beta vulgaris), 41\% for 'Red Baron' radish (Raphanus sativus), 59\% for 'Maestro' pea (Pisum sativum), 67\% for 'Comanche' onion (Allium cepa), 68\% for 'Black Seeded Simpson' lettuce (Lactuca sativa), 71\% for 'Provider' bean (Phaseolus vulgaris), and 73\% for 'Scarlet Nantes' carrot (Daucus carota) compared to the control. These findings resulted in a recommendation not to apply CGM even at the lowest application rate $\left(100 \mathrm{~g} \cdot \mathrm{m}^{-2}\right)$ to direct-seeded vegetables (McDade \& Christians, 2000). Webber and Shrefler (2007b) determined that broadcast applications of CGM as low as $100 \mathrm{~g} \cdot \mathrm{m}^{-2}$ significantly decreased the establishment of direct-seeded black bean 'Black Knight', pinto bean 'Apache', cantaloupe (Cucumis melo) 'Magnum 45' and watermelon (Citrullus lanatus) 'Allsweet' by 66\%, $58 \%, 50 \%$, and $58 \%$, respectively. Webber and Shrefler $(2007 \mathrm{~b})$ suggested the potential usefulness of CGM application for direct-seeded vegetables by restricting CGM to the interrow area while leaving a CGM-free application area for the direct-seeding of vegetable crops.

A mechanized applicator was developed and evaluated to apply CGM in a banded configuration (Webber \& Shrefler, 2007a). The applicator was constructed using various machinery components (fertilizer box, rotating agitator blades, $12-\mathrm{V}$ motor, and fan shaped, gravity-fed, row banding applicators). The equipment was evaluated for the application of two CGM formulations (powdered and granulated), three application rates $(250,500$, and $750-\mathrm{g} \cdot \mathrm{m}^{-2}$ ), and two application configurations (solid and banded). Differences between CGM formulations affected flow rate within, and between, application configurations. The granulated formulation flowed at a faster rate, without clumping, compared to the powdered formulation, while the CGM in the banded configuration flowed faster than the solid application. Webber and Shrefler (2007a) demonstrated the feasibility of using equipment, rather than manual applications, to apply CGM to raised beds for organic weed control. The development of equipment to apply CGM in banded configurations created an opportunity to investigate whether banded CGM applications would provide significant crop safety for direct-seeded vegetables.

As a result of the development of a mechanized application system for the banded placement of CGM between crop rows (seed row not treated) Webber et al. (2010) 
investigated the impact of CGM applications (formulations, rates, incorporation, and banded applications) on direct-seeded squash (Cucurbita pepo) plant survival and yields. It was determined that neither CGM formulation (powdered or granulated), nor incorporation method (incorporated or non-incorporated), resulted in significant differences in plant survival or squash yields. When average across all other factors (formulations, incorporation method, and banding), CGM rates of 250 to $750-\mathrm{g} \cdot \mathrm{m}^{-2}$ reduced squash survival from $70 \%$ to $44 \%$, and squash yields from 6402 to $4472-\mathrm{kg} \mathrm{ha}^{-1}$. However, the banded application (CGM placed between rows) resulted in significantly greater crop safety, 75\% survival, and yields, $6402 \mathrm{~kg} \cdot \mathrm{ha}^{-1}$, than the broadcast (non-banded) applications, 35\% survival and $4119 \mathrm{~kg} \cdot \mathrm{ha}^{-1}$ yields. It was demonstrated that banded applications of CGM can be useful in direct-seeded squash production and other organic direct-seeded vegetables.

\subsubsection{Mustard seed meal}

Mustard seed meal (MSM) is the by-product of the seed oil pressing process. Research has shown that MSM added to the soil inhibited weed emergence and growth (Ascard \& Johansson, 1991; Boydston, 2008; Boydston et. al., 2008, 2011; Miller, 2006, Webber et al., 2009a). As with CGM, MSM is a non-selective natural herbicide that will not discriminate between weeds and crop plants, therefore, care must be taken to control the target species (weeds) and provide sufficient crop safety. Among other crops, MSM has been used to control weeds in turf (Earlywine et al., 2010), onion (Boydston et al., 2011), ornamentals (Boydston et al., 2008), potato, Solanum tuberosum L., (Boydston, 2008), and peppermint, Mentha $\times$ piperita L., (Boydston, 2008). Research has shown that the range of weeds controlled or suppressed by MSM is very extensive (Ascard and Johansson, 1991; Boydston, 2008; Boydston et al., 2011; Earlywine, 2010; Handiseni et al., 2011; Vaughn et al., 2006; Webber 2009a; Yu \& Morishita, 2011). A partial list of weeds inhibited by MSM would include redroot pigweed (Amaranthus retroflexus L.), green foxtail (Setaria viridis (L.) Beauv.), kochia (Kochia scoparia (L.) Schrad.), Russian-thistle (Salsola tragus L.), common lambsquarters (Chenopodium album L.), barnyardgrass (Echinochloa crus-galli L. Beauv.), annual sowthistle (Sonchus oleraceus L.), buckhorn plantain (Plantago lanceolata L.), common chickweed (Stellaria media (L.) Vill.), large crabgrass (Digitaria sanguinalis L. Scop.), Italian ryegrass (Lolium perenne L. spp. multiflorum Lam. Husnot), prickly lettuce (Lactuca serriola L.), and wild oat (Avena fatua L.) (Boydston et al. 2011; Earlywine et al., 2010; Handiseni et al., 2011; Yu \& Morishita, 2011).

Yu and Morishita (2011) compared weed control efficacy of MSM and CGM at 3 rates (2240, 4480 , and $6720 \mathrm{~kg} \mathrm{ha}^{-1}$ ) at two locations for five broadleaf and two grass weed species. Yu and Morishita concluded that MSM provided, in general, had a greater weed control efficacy than CGM. The species of mustard can also influence the weed control efficacy. Hoagland et al. (2008) determined that MSM from Sinapis alba L. produced as good or greater phytotoxicy and was more consistent than MSM produced from Brassica napus L. and B. Juncea L.

It is essential to understand that as non-selective herbicides, CGM and MSM can injure or kill germinating and emerging crop seedlings. Crop safely is greater when these substances are applied to established annual or perennial plants. Although CGM and MSM can provide effective early preemergence weed control of germinating weed seeds, supplemental weed control measures will be required to control escaped weeds, established perennial weeds, or weeds emerging in the mid- to late-growing season. Most, if not all, organic certificating entities prohibit the use CGM and MSM derived from genetically modified organisms 
(GMO). Although organic materials are naturally derived, care should always be taken to safely handle and apply the materials. For example, MSM can cause extreme dermal reaction in humans and should be used with suitable protective equipment.

Researchers have identified other seed and plant components that natural inhibit plant growth (allelopathy) (Chung et al., 1997; Kuk et al., 2001; Rice, 1984; Tamak et al., 1994a, 1994b). Hopefully, research will continue to develop suitable organic herbicides from not only seed meals, but from other plant components.

\subsubsection{Post-emergence, post-directed, and burndown organic herbicides}

The organic post-emergence, post-directed, and burndown herbicides are all non-selective, non-translocated, contact herbicides which need to be applied, either prior to crop emergence or transplanting, or post-directed to established crops to assure the herbicides do not injure the crop plant. In general these contact herbicides control broadleaf weeds better than grasses, smaller weeds better than larger weeds, and annual weeds better than perennial weeds. These herbicides destroy the plant's waxy cuticle and cell walls causing desiccation and rapid wilting, which is further improved with uniform application of the material. Depending on the herbicide, an adjuvant may increase the herbicidal activity by increasing the destruction of the cuticle and cell wall, or by providing a more uniform application. Read and follow the label to determine whether an adjuvant is required and, if so, what type of adjuvant and mixture rate.

\subsubsection{Ammonium nonanoate}

Racer ${ }^{\circledR}(40 \%$ ammonium Nonanoate) is a soap formulation of pelargonic acid with a changing registration history. It is a non-selective contact herbicide for controlling small (2.5 to $5 \mathrm{~cm}$ tall) annual broadleaf and grass weeds (Webber et al., 2011a). Repeated applications may be needed to control most grasses or larger $(5 \mathrm{~cm})$ broadleaf weeds. It has been cleared for non-crop use in organic crop production and with addition of new formulations may be cleared for use in organic crop production. Organic producers should receive clearance from their certifying agency prior to using Racer.

\subsubsection{Fatty acids}

A recent National Organic Program (NOP) ruling decided that pelargonic acid is a prohibited substance for organic crop production. Until the recent ruling, pelargonic acid, a fatty acid, had tremendous potential as an organic herbicide. It had proven effective as a non-selective post-emergent contact herbicide (Webber et al., 2011b). It provided excellent weed control at low application rates and volumes, but has not been cleared due to its manufacture by synthetic methods. In addition to pelargonic acid, other fatty acids are under consideration and development as potential organic herbicides.

\subsubsection{Vinegar $(5,10,15$, and $20 \%$ acetic acid)}

There are a number of organically approved products that contain vinegar (e.g., Weed Pharm ${ }^{\circledR}, 20 \%$ Acetic Acid) that contain vinegar (e.g., 5\%, 10\%, and 20\% acetic acid). Vinegar (acetic acid) is a non-selective contact herbicide. In general, weed control increases as acetic acid content and application volume increase (e.g., 20, 40, 80, and 100 gpa). Typically, vinegar is less effective in controlling grasses than broadleaf weeds and more effective on 
annual species than perennials (Webber and Shrefler, 2007c, 2008a, 2008b, 2009b; Webber et al., 2009b). In addition to application volumes and concentration, weed control is also dependent on the weed size and the species. Carpetweed (Mollugo verticillata L.) is very sensitive to acetic acid at very low concentrations and application volumes, while yellow nutsedge (Cyperus esculentus L.) is able to tolerate high acetic acid concentrations and application volumes. Repeated applications of acetic acid may be necessary for satisfactory weed control depending on weed size, weed species, and whether it is an annual or perennial plant. There is also a difference between non-synthetic and synthetic acetic acid and approval for use in organic production. If the material is intended for use on certified organic land, check for approval of your specific product with your organic certifying agency. Also keep in mind that clearance for organic use does not mean a product can not cause personal injury, if handled in an unsafe manner. Vinegar with greater than $10 \%$ acetic acid can cause severe eye damage or even blindness.

\subsubsection{Clove oil}

Clove oil is the active ingredient in a number of organically approved post-emergent nonselective herbicides (e.g. Matratec ${ }^{\circledR}$, Matran ${ }^{\circledR}$ EC and Matran $\AA$, 50\% Clove Oil). Clove oil is a post-emergence, non-selective, contact herbicide for the control of actively growing emerged annual and perennial grass and broadleaf weeds. As a contact, non-translocated herbicide its effectiveness increases with application rate and decreasing weed size. As with the other contact herbicides, when weeds are of similar size, the broadleaf weeds are easier to control than the grasses (Webber and Shrefler, 2009a; clove oil weed control efficacy can be as good, or better than acetic acid herbicides, and can be applied at lower application volumes and remain effective. There is evidence that adding certain organically approved adjuvants (e.g., garlic and yucca extracts) will increase weed control with clove oil. Repeated applications may be necessary because larger annual grass weeds may grow back.

\subsubsection{D-limonene}

GreenMatch ${ }^{\circledR}(55 \%$ d-limonene) is a post-emergence, non-selective, contact herbicide for control on actively growing emerged annual and perennial grass and broadleaf weeds. Shrefler et al. (2011) used d-limonene as a post-directed control of weeds in organic cantaloupe and Lanini et al (2010) conducted greenhouse and field studies using dlimonene. As with the other organic contact herbicides, d-limonene, in general, has greater efficacy on younger smaller weeds than larger older weeds, and greater control of broadleaf weeds than grass weeds (Lanini et al., 2010).

\subsubsection{Organic herbicide conclusions}

Additional active ingredients and formulations are also being developed. Approval of these involves conducting greenhouse screenings, and progressing to extensive field evaluations. Even if all these active ingredients and their commercial formulations are registered by EPA and approved for organic use, the application technology and timing will play an essential element in their successful integration into existing certified organic systems. Research with post-directed applications of non-selective contact herbicides is showing promise. The height and plant maturity differences between the crop and target weeds are important factors in controlling weeds and protecting the crop from herbicide damage. The postdirected technique is especially effective when used in combination with either preemergence corn gluten meal applications or transplanted crops. 


\subsubsection{Herbicide precautions}

Always read and follow the herbicide labels, take appropriate safety precautions, and don't hesitate to contact your certifying agency prior to applying any substance.

\section{Summary}

Controlling weeds is an essential aspect of successful crop production. The lack of weed control can result in the total yield loss due to weed competition and with weeds acting as a reservoir for pathogens through disease and insect damage. Weed control should be considered a continuous endeavor not just a seasonal effort. It is more cost effective to prevent an infestation than eliminating a weed species once the production area is infested. Weed control should start in the previous crop, by monitoring, controlling, and managing the weeds. Successful weed management uses a multifaceted approach (rotating crops and herbicides, cover crops, mulches, cultivation) rather than relying solely on herbicides to control the weeds. Knowing which weeds will be present and understanding their growth habits will enable the producer to achieve greater weed control by the wise application of the many weed control methods available.

\section{References}

Ascard, J. \& Johansson, T. (1991). White mustard meal interesting for weed control, In: Weeds and Weed Control Reports. Proceedings of 32nd Swedish Crop Protection Conference. Swedish University of Agricultural Sciences, Stockholm, Sweden. p. 139-155.

Biazzo, J. \& Masiunas, J.B. (1998) Using living mulches for weed control in Hungarian wax pepper (Capsicum annuum) and okra (Abelmoschus esculentus). Illinois Fruit and Vegetable Crop Research Report. University of Illinois - Champaign.

Bingaman, B.R. \& Christians, N.E. (1995) Greenhouse screening of corn gluten meal as a natural control for broadleaf and grass weeds. HortScience 30:1256-1259.

Boydston, R.A. (2008) Mustard meal suppresses weeds in potato and peppermint. Proceedings Western Society of Weed Science, Anaheim, CA, USA. March 2008.61:37.

Boydston, R.A., Anderson, T. \& Vaughn, S.F. (2008) Mustard (Sinapis alba) seed meal suppresses weeds in container-grown ornamentals. HortScience 43:800-803.

Boydston, R.A., Morra, M.J., Borek, V., Clayton, L. \& Vaughn, S.F.(2011) Onion and Weed Response to Mustard (Sinapis alba) Seed Meal. Weed Science In-Press. Online. doi: 10.1614/WS-D-10-00185.1

Christians, N.E. (1991) Preemergence weed control using corn gluten meal. U.S. Patent No. 5,030,268 p.63-65. United States Patent and Trademark Office. Washington D.C.

Christians, N.E. (1993) The use of corn gluten meal as a natural preemergence weed control in turf. Intl. Turfgrass Soc. Res. J. 7:284-290.

Christians, N.E. (1995) A natural herbicide from corn meal for weed-free lawns. IPM Practitioner 17(10):5-8.

Chung, I.M., K.H. Kim, K.H., Ahn, J.K. \& Ju, H.J. (1997) Allelopathic potential evaluation of rice varieties on Echinochloa crus-galli. Kor. J. Weed Sci. 17:52-58.

Clark, S. and Panciera, M. (2002) Cover crop roll-down for weed suppression in no-till crop production. Fruit and Vegetable Crops Research Report. Univ. Kentucky Agr. Expt. Sta. p. 56-57.

Darlington, H.T. \& Steinbauer, G.P. (1961) The eighty-year period for Dr. Beal's seed viability experiment. American J. of Botany 48: 321-325. 
Dick, W.A. (1983). Organic carbon, nitrogen and phosphorus concentrations and $\mathrm{pH}$ in soil profiles as affected by tillage intensity. Soil Sci. Soc. Am. J. 47:102-107.

Decoteau, D.R., Kasperbauer, M.J. \& Hunt, P.G. (1990) Bell pepper plant development over mulches of diverse color. HortScience 25:460-462.

Earlywine, D.T., Smeda, R.J., Teuton, T.C., Smas, C.E., \& Xiong, X. (2010) Evaluation of oriental mustard (Brassica juncea). Weed Tchnology 24:440-445.

Gallaher, R.N. \& Ferrer, M.B. (1987) Effect of no-tillage vs. conventional tillage on soil organic matter and nitrogen contents. Commun. Soil Sci. Plant Anal. 18:1061-1076.

Georgia, A. (1942) Manual of weeds. Macmillan, New York. 593 p.

Handiseni, M., Brown, J., Zemetra, R. \& Mazzola, M. (2011) Herbicidal activity of brassicaceae seed meal on wild oat (Avena fatua), Italian ryegrass (Lolium multiflorum), redroot pigweed (Amaranthus retroflexus), and prickly lettuce (Lactuca serriola) Weed Technology 25:127-134 doi: 10.1614/WT-D-10-00068.1

Hauptli, H. \& Jain, S.K. (1978) Biosystematics and agronomic potential of some weedy and cultivated amaranthus. Theoretical and Applied Genetics 52, 177-185.

Hoagland, L., Carpenter-Boggs, L., Reganold, J.P. \& Mazzola, M. (2008) Role of native soil biology in Brassicaceous seed meal-induced weed suppression. Soil Biology and Biochemistry 40:1689-1697.

Johnson, A.E. (1986) Soil organic matter, effects on soil and crops. Soil Use Management. 2:97-105.

Johnson, W.C., III, Davis, R.F. \& Mullinix, B.G., Jr. (2007). An integrated system of summer solarization and fallow tillage for Cyperus esculentus and nematode management in the southeastern coastal plain. Crop Protection 26:1660-1666.

Johnson, W.C., III, \& Mullinix, B.G., Jr. (2008) Potential weed management systems for organic peanut production. Peanut Sci. 35:67-72.

Kaul, K. \& Kasperbauer, M.J. (1992) Mulch color effects on reflected light, rhizosphere temperature, and pepper yield. Transactions Kentucky Academy of Science 53, 109-112.

Kuk, Y., Burgos, N.R., \& Talbert, R.E. (2001) Evaluation of rice by-products for weed control. Weed Science 49:141-147.

Lanini, W.T., Capps, L., \& Roncoroni, J.A. (2010) Field testing of organic herbicides. Proceedings of the Western Society of Weed Science. Waikoloa, Hawaii, USA. March 2010. 63:13.

Law, D.M., Rowell, A.B., Snyder, J.C. \& Williams, M.A. (2006) Weed control efficacy of organic mulches in two organically managed Bell Pepper production systems. HortTechnology 16:225-231.

Leavitt, M.J., Sheaffer, C.C., Wyse, D.L. \& Allen, D.L. (2011) Rolled winter rye and hairy vetch cover crops lower weed density but reduced vegetable yields in no-tillage organic production. HortScience 46(3), 387-395.

Logan, T.J., Lal, R. \& Dick, W.A. (1991). Tillage systems and soil properties in North America. Soil Tillage Res. 20:241-270.

McDade, M.C. (1999) Corn gluten meal and corn gluten hydrolysate for weed control. M.S. Thesis, Iowa State Univ. Dept. of Hort., Ames, IA.

McDade, M.C. \& Christians, N.E. (2000) Corn gluten meal - a natural preemergence herbicide: effect on vegetable seedling survival and weed cover. Amer. J. Alternative Agr. 15(4):189-191.

McDowell, L.L. \& McGregor, K.C. (1984) Plant nutrient losses in runoff from conservation tillage corn. Soil and Tillage Research 4:79-91.

McGiffen, Jr., M.E. \& Hutchinson, C. (2000) Cowpea cover crop mulch controls weeds in transplanted Peppers. HortScience 35:462. 
Miller, T.W. (2006) Natural herbicides and amendments for organic weed control In: Crop Protection Products for Organic Agriculture. ACS Symposium Series 947, A.S. Felsot and K.D. Racke (eds.). p.174-175. American Chemical Society, Washington, D.C.

Mitich, L.W. (1997) Intriguing world of weeds - Redroot pigweed (Amaranthus retroflexus). Weed Technology 11, 199-202.

Mohler, C.L. and Callaway, M.B. (1995) Effects of tillage and mulch on weed seed production and seed banks in sweet corn. J. of Applied Ecology 32, 627-639.

Nonnecke, G.R. \& Christians, N.E. (1993) Evaluation of corn gluten meal as a natural weed control product in strawberry. Acta Hort. 348:315-320.

Organic Farming Research Foundation (OFRF) (1999). Final results of the third biennial national organic farmers' survey. Santa Cruz, CA, USA. 161 pages.

Organic Farming Research Foundation (OFRF). (2006) On-farm testing of organic weed control strategies in Indiana. Project report summary. Santa Cruz, CA, USA.

Paine, L.K. \& Harrison, H. (1993) The historical roots of living mulch and related practices. HortTechnology 3(2), 137-143.

Pawlowski, F., Kapeluszny, J., Kolasa, A. \& Lecyk, Z. (1970) The prolificacy of weeds in various habitats. Annales Universitatis Mariae Curie, Sklodowska Lublin, Polonia, 25:61-75.

Pekrun, C., El Titi, A. \& Claupein, W. (2003). Implications of soil tillage for crop and weed seeds. In: Soil Tillage in Agroecosystems, A. El Titi, Editor, pp. 115-146. CRC Press, Boca Raton, FL.

Quarles, W. (1999). Corn gluten meal: a least-toxic herbicide. The IPM Practitioner 21:1-7.

Rice, E.L. (1984) Allelopathy. Orlando, Florida: Academic Press (Second Edition).

Russo, V.M. (1995) Bedding, plant population, and spray-on mulch tested to increase dry bean yield. HortScience 30:53-54.

Russo, V.M., Webber, C.L., III, \& Myers, D.L. (1997) Kenaf extract affects germination and post-germination development of weed, grass and vegetable seeds. Industrial Crops and Products 6:59-69.

Shrefler, J., Webber III, C.L., Taylor, M.J., \& Roberts, B.W. (2011). Weed management options for organic cantaloupe production. Proceeding of the Weed Science Society of America. Portland, OR, USA. Feb. 2011. Poster \# 51. URL http://wssaabstracts.com/public/4/proceedings.html

Stevens, O.A. (1932) The number and weight of seeds produced by weeds. American J. of Botany 19, 784-794.

Stevens, O.A. (1957) Weights of seeds and numbers per plant. Weeds 5:46-55.

Tamak, J.C., Narwal, S.S., Singh, L. \& Ram, M. (1994a) Effect of aqueous extracts of rice stubbles and straw 1 stubbles on the germination and seedling growth of Convolvulus arvensis, Avena ludoviciana, and Phalaris minor. Crop Res. 8:186-189.

Tamak, J.C., Narwal, S.S., Singh, L. \& Singh, I. (1994b) Effect of aqueous extracts of rice stubbles and straw 1 stubbles on the germination and seedling growth of wheat, oat, berseen, and lentil. Crop Res. 8:180-186.

Teasdale, J. \& Mohler, C. (2000) The quantitative relationship between weed emergence and the physical properties of mulches. Weed Science 48:385-392.

United States Department of Agriculture (USDA) National Organic Standards Board (2010) Policy and Procedures Manual. United States Department of Agriculture, Washington, D.C.

Vaughn, S.F., Palmquist, D.E., \& Duval, S.M. (2006) Herbicidal activity of glucosinolatecontaining seedmeals. Weed Science 54:743-748. 
Weaver S.E. \& McWilliams, E.L. (1980) The biology of Canadian weeds: Amaranthus retroflexus L., A. powellii S. Wats. and A. hybridus L. Canadian J. of Plant Science 60: 1215-1234.

Webber, C.L. III \& J.W. Shrefler. (2007a) Corn gluten meal applicator for weed control in organic vegetable production. J. Veg. Crop Production 12:19-26. 2007.

Webber, C.L. III \& Shrefler, J.W. (2007b) Impact of corn gluten meal applications on directseeded vegetable seedling establishment. Intl. J. Veg. Sci. 13:5-15.

Webber, C.L. III \& Shrefler, J.W. (2007c) Organic weed control with vinegar: Application volumes and adjuvants. Proceedings of Horticultural Industries Show. Ft. Smith, AR, USA. Jan. 2007. 26:149-151.

Webber, C.L. III, Shrefler,J.W. \& Taylor, M.J. (2007a) Corn gluten meal as an alternative weed control option for spring-transplanted onions. Intl. J. Veg. Sci. 13:17-33.

Webber, C.L. III, Shrefler, J.W. \& Taylor, M.J. (2007b) Impact of corn gluten meal applications on spring-transplanted onion (Allium cepa) injury and yields. Intl. J. Veg. Sci. 13:5-20.

Webber, C.L. III \& Shrefler, J.W. (2008a) Acetic acid and weed control in onions (Allium cepa L.). Proceedings of National Allium Research Conference. Dec. 2008. Savannah, GA, USA. p. 49-54.

Webber, C.L. III \& Shrefler, J.W. (2008b) Acetic acid: Crop injury and onion (Allium cepa L.) yields. Proceedings National Allium Research Conference. Dec. 2008. Savannah, GA, USA. p. 55-59.

Webber, C.L. III \& Shrefler, J.W. (2009a) Broadcast application of Matran for broadleaf weed control in spring-transplanted onions. In: 2008 Weed Control Report. Brandenberger, L. and Wells, L. (eds.). MP-162:17-19. Oklahoma State University, Division of Agricultural Sciences and Natural Resources, Department of Horticulture \& Landscape Architecture. Stillwater, OK, USA.

Webber, C.L. III \& Shrefler, J.W. (2009b) Broadcast application of vinegar for broadleaf weed control in spring-transplanted onions. In: 2008 Weed Control Report. Brandenberger, L. and Wells, L. (eds.). MP-162:26-28. Oklahoma State University, Division of Agricultural Sciences and Natural Resources, Department of Horticulture \& Landscape Architecture. Stillwater, OK, USA.

Webber, C.L. III, Shrefler, J.W., \& Boydston, R.A. (2009a) Mustard Meal as an Organic Herbicide. Proceedings of the Joint 49th Weed Science Society of America and 62nd Southern Weed Science Society. Orlando, FL, USA. Feb. 2009. p. 80.

Webber, C.L. III, Shrefler, J.W., Brandenberger, L.P., Taylor, M.J. \& Boydston, R.A. (2009b) 2008 Organic herbicide update. Proceedings of the Horticultural Industries Show. Ft. Smith, AR, USA. Jan. 2009. p. 237-239.

Webber, C.L. III, Shrefler, J.W., \& Taylor, M.J. (2010) Influence of Corn Gluten Meal on Squash Plant Survival and Yields. HortTechnology 20:696-699.

Webber, C.L. III, Brandenberger, L.P., Shrefler, J.W., Taylor, M.J., Carrier, L.K. \& Shannon, D.K. (2011a) Weed control efficacy with ammonium nonanoate for organic vegetable production. Int. J. Veg. Sci. 17:1-8.

Webber, C.L. III, Shrefler, J.W. \& Brandenberger, L.P. (2011b) Scythe ${ }^{\circledR}$ (pelargonic acid) weed control in squash. In: 2010 Weed Control Report. Brandenberger, L. and Wells, L. (eds.). MP-162:20-23. Oklahoma State University, Division of Agricultural Sciences and Natural Resources, Department of Horticulture \& Landscape Architecture. Stillwater, OK, USA.

Yu, J. \& Morishita, D.W. (2011) Greenhouse screening of corn gluten meal and mustard seed meal as natural weed control products. Proceedings of the Western Society of Weed Science. Spokane, WA, USA. March 2011, Abstract \#60. (http://wssaabstracts.com/ public/6/abstract-60.html) 


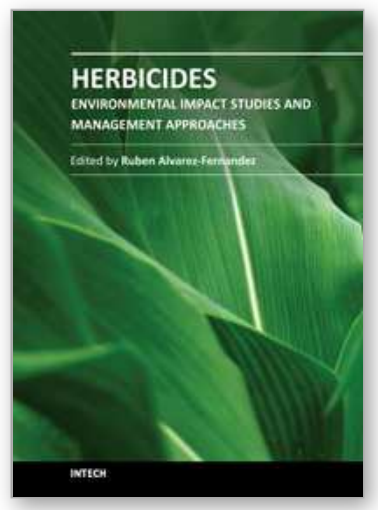

\section{Herbicides - Environmental Impact Studies and Management Approaches}

Edited by Dr. Ruben Alvarez-Fernandez

ISBN 978-953-307-892-2

Hard cover, 248 pages

Publisher InTech

Published online 20, January, 2012

Published in print edition January, 2012

Weeds severely affect crop quality and yield. Therefore, successful farming relies on their control by coordinated management approaches. Among these, chemical herbicides are of key importance. Their development and commercialization began in the 1940's and they allowed for a qualitative increase in crop yield and quality when it was most needed. This book blends review chapters with scientific studies, creating an overview of some the current trends in the field of herbicides. Included are environmental studies on their toxicity and impact on natural populations, methods to reduce herbicide inputs and therefore overall non-target toxicity, and the use of bioherbicides as natural alternatives.

\section{How to reference}

In order to correctly reference this scholarly work, feel free to copy and paste the following:

Charles L. Webber III, James W. Shrefler and Lynn P. Brandenberger (2012). Organic Weed Control, Herbicides - Environmental Impact Studies and Management Approaches, Dr. Ruben Alvarez-Fernandez (Ed.), ISBN: 978-953-307-892-2, InTech, Available from: http://www.intechopen.com/books/herbicidesenvironmental-impact-studies-and-management-approaches/organic-weed-control

\section{INTECH}

open science | open minds

\section{InTech Europe}

University Campus STeP Ri

Slavka Krautzeka 83/A

51000 Rijeka, Croatia

Phone: +385 (51) 770447

Fax: +385 (51) 686166

www.intechopen.com

\section{InTech China}

Unit 405, Office Block, Hotel Equatorial Shanghai

No.65, Yan An Road (West), Shanghai, 200040, China

中国上海市延安西路65号上海国际贵都大饭店办公楼405单元

Phone: +86-21-62489820

Fax: $+86-21-62489821$ 
(C) 2012 The Author(s). Licensee IntechOpen. This is an open access article distributed under the terms of the Creative Commons Attribution 3.0 License, which permits unrestricted use, distribution, and reproduction in any medium, provided the original work is properly cited. 